\title{
The Hydraulic Propeller as A Motive Power for Ships
}

\author{
Vice-Admiral G. Elliot
}

To cite this article: Vice-Admiral G. Elliot (1868) The Hydraulic Propeller as A Motive Power for Ships, Royal United Services Institution. Journal, 11:47, 589-611, DOI:

$10.1080 / 03071846809417320$

To link to this article: http://dx.doi.org/10.1080/03071846809417320

册 Published online: 11 Sep 2009.

Submit your article to this journal $₫$

Џ Article views: 7

Q View related articles $\sqsubset$ 


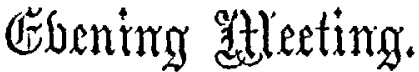

Monday Evening, June 10th, 1867.

VICE-ADMrnAL. SIr IIENRY J. CODRINGTON, K.C.B., in the Chair.

NAIDES OF IICIIBERS who joined the Institution between the Srd and 10th of June, 1867.

ANNUAL.

Bateman, Richard S., Commander R.N.

Sloane, C. E. C. D., Captain Rogal Sherwood Foresters Militia. $1 l$.

Watcrhouse, IIenry, Captain Lanark Artillery Voluntecrs.

Palk, Lawrence II., Lieut. Scots Fusilier Guards. $1 l$.

\section{TIIE IIYDRAULIC PROPELLER AS A MOTIVE POWER FOR SIIIPS.}

\section{By Vice-Admiral G. EuLioT.}

The Charnsias: I beg to introduce to you Admiral Elliot who has been liud enougin to come here and instruct us this erening on the subject of a new motive porrer for ships. To many of us it will be $\mathrm{new}$, and I am sure we shall all gain considerably by the information he is about to give us.

Admiral Ethior: It is not my intention to attempt any cxposition of the various laws of hydraulics or scientific principles involved in the application of water to the purpose of propelling vessels. MYy opinion is that the laws of science which operate in the practical derclopment of this invention are few and simple, and easily understood; and that it is owing to looking too far into the maze of science, that some clever men have fallen into such errors in prophesying the non-success which would attend this new application of water power. I regret to say that the invention has suffered much from the treatment it has received at the hands of some scientific men; but having now reached the region of success, we can afford to be generous and to furget the past: and all we ask is, that in the face of indisputable realizations of Mr. Ruthven's anticipations, and on account of the great importance of this invention for war purposes, and the enormous advantages it opens out to the science of naval architecture, our scientific opponents will in future come forward openly, and honestly support their views by argument, discussion, and proofs, as opposed to the facts wo now have to lay beforo them. 
Were I to refer to the correspondence I have carricd on for years, and show you the annoynces and disappointments I have met with, it would prore how thankless and hopeless a task it is, to become a. pioneer in the cause of improvement. But if men who well know the weight of their opinions, will still continue to disparage this invention, refusing to accept the evidence of facts, it may retard the development of this new propeller, but I am convinced that it cannot prohibit its final adoption for general use.

I wish this evening to cout free discussion. I will lay before you a short description of the history of this invention up to the present time, with a statement of the facts which have been realized, and I will endeavour to point out the principal features, in which this new propeller will show its great superiority over the screw or paddle. 1 regret to say that I come before you not so well prepared as I could have wished, as circumstances liave not permitted me to devote the time which I should have desired to the preparntion of this paper. I do not come here to puff up an invention, nor to make personal attacks on any one, but to meet my brother Officers in friendly discussion on a point which I ani sure will interest them all; and to add my support to the proccedings of this very valuable Institution.

The idea of propelling vessels by water is very old, and many attempts have at various periods been made to adapt the theory to practice, but all unsuccessfully, until Mr. Ruthven, of Edinburgh, an engineer, in the year 1839, inrented an apparatus for doing so. Under the patent then obtained, two small ressels were constructed-one of nine feet long, with steam power, and afterwards in 1844, another of forty feet. These ressels were exhibited, the smaller one on the Union Canal at Edinburgh, and the larger one on the Forth. They attracted a great deal of attention at the time, and were very highly spoken of. They had been broughit under the notice of the Admiralty by Officers of the Navy, and so farourably recommended that the Admiralty requested permission to inspect and experiment on the last-named vessel, and a report, which was highly faromable, was duly made on her performances by MIr. Murray, the present Chief Engineer of Portsmouth Dockyard. Great exertions were then made by the inventor to hare the inrention taken ap, but he was entirely unsuccessful. Few appeared to know anything of the principles upon which the ressel was propelled; and the scientific and practical people were alike opposed to it. In 18.19 a few improrements were made upon certain parts of the apparatus, for which a new patent was taken out. Fresh efforts to introduce it were again made, and another small ressel, thirty feet long, was built to illustrate the invention. This ressel was placed on the Thames. A smaller one, of twelve feet, was sent to the Great Exhibition in 1851. The one on the Thames attracted, as might have becn expected, a great deal of notice, and was by many most favourably spoken of ; and one Steamboat Company proposed taking up the invention, but ultimately abandoned their intention stating that if successful, it rould throw out of use the many boats they had then on the river. The model in the Exhibition fared worse, though it pretended to be, and in reality was, one of the most raluable 
iurentions for commercial purposes in the whole exhibition; it was not so much as even noticed in the jurors' report. It was not until 1853, that the first vessel for commercial purposes was made and completed. This resscl called the "Alvert," was built in Prussia, partly at the expense of the Prussian Government, by a Mr. Sydel, and the engines and other machinery were furnished by the patentee. It has been employed ever since, running regularly on the 0der, and has proved the complete success of the invention.

Since then, another vessel with this new system of propulsion, called the "Seraing," has been built at Antwerp, and I induced the Admiralty to send over Mr. Murray, Chief Engineer at Portsmouth, to examine and report upon her capalilities. I have a copy of the letter which was sent to the Admiralty by Mrr. Murray after he had inspected the vessel, but it is too long to read it through. He reported favorably of what he saw, and recommended this mode of propulsion for adoption, especially for mar resscls; although as far as the inconclusive evidence he obtained would enable him to judge of the speed obtained, as compared with the paddle in a sister ressel, it appeared that the hydraulic propeller as applied to the "Seraing;" liad a loss of speed of somewhat less than one-tenth. "The 'Scraing' was 130 feet long over all, 13 feet beam, and about 8 feet deep with a draught of water of about 3 fect. The engines are of 40-horse nominal porrer, with two cylinders of 24 inches diameter and 22 inches stroke, making 50 to 52 revolutions per minute, and working horizontally and direct upon the vertical shaft of a centrifugal pump."

I may mention with regard to this vessel that the drawings of ber engines did not come from Mr. Ruthven, and that there is an alteration made in the discharge pipes which Mr. Ruthven objected to. But I an only carrying the listory up to the present time. We shall presently see what facts we hare arrived at, when Mr. Ruthren had his own way entirely.

Notwithstanding having two veritable ressels to refer to, both of which displayed considerable success, the same opposition was still made to the hydrnulic propeller, so that nothing towards its derelopment was done in this country until 1862, when in consequence of my urgent applications to the Admiralty, an order was given for an experiment to be made to test the hydraulic power, in a gunboat at Devonport. But it will hardly be believed that no one connected with the invention was consulted; and when it was discorered that the experiment was being made, and Mr. Ruthren went down to look at it, he found to his surprise that it was no child of his at all! the invention had been misapplied, and as he would not adopt it, this first Government experiment was unproductive. Well, that was the result of $\mathrm{my}_{\mathrm{y}}$ first application to the Admiralty. But I never ceased my importunities until I obtained permission, in 1804, to have the lyydraulic propeller fitted to the "Waterwitch."

I must say that I ove it entirely to the Controller of the Navy that this trial was made in the "Waterwitch." I am certain that if it had not been for him, the trial rrould not have been made. At that time the aspect of affairs was very cloudy indeed, in consequenco of the oppo- 
sition of scientific men, so that the responsibility was far greater to those who recommended the experiment to be tried in the "Waterwitch" then, than it would be to order its application on a larger scale now.

IIere is an exact model of the "Waterwitch," not of her fittings, but of her form below the water-line, On secing that it was a clumsy vessel, and thinking it might be desirablo to get more speed, I proposed to take the same draught of water and the same displacement, and I sent up drawings of an iron vessel in which I proposed to put the hydraulic propeller. But it was said, as we are building two other vessels of this class; the "Vixen," and the "Viper," if wo put the hydraulic in a vessel exactly like them in all respects, the trial will be so much the more convincing if it turns out that they have equal speed. I saw something in that argument, and of course I agreed to it at once. I. was desired, with Mr. Ruthrea and Mr. Murray, to prepare an engine for the " Waterwitch," which was done. I speak upon this point, particularly, because it has since been thrown out that the success which has attended this trial is not convincing, because the " Waterwitch" class of vessel is a very clumsy one to drive. I do not consider myself that this has anything to do with it. I think that to get 10 knots with 160-horse power out of such coarse lines, is perhaps more creditable than to get 11 or 12 knots out of a ressel with a finer water-line, a longer vessel, and an casier ressel to drive. That has nothing to do with the question. There is a certain power exerted, and there has been a certain amount of work done; and that is proof of the merits of the hydraulic propeller at the present time. All scientific men can easily make out whether it has succeeded or not. I think it is a very fair trial. If the ressels had been of finer lines, there would have been less work to do, and the same power would have obtained greater speed. I cannot understand why the trial, as it stands between the "Viper" and the " Wraterwitch," is not just as fair as if they had been vessels built on faster lines. As a comparative test it is equally conclusire.

The drawings of the enrines were prepared by Mr. Ruthven, assisted by Mr. Murray, and by Mr. Dudgeon, who hns always lent us every assistance in his power. These are the engines in the "Waterwitch," (see diagram,) only they lave thrce cylinders. I believe Mr. Ruthven rather prefers two; Mir. Dudgeon says he prefers three. It is a question which is best. No doubt, with two cylinders you get less friction, and with threc you get more easy motion, but there, is greater weight of engine, and I believe Mrr. Ruthren still holds to his opinion that two cylinders, in certain circumstances, are better than three.

The results of all these trials are upon the paper in my hand. They are the Admiralty Reports :-on the "Vixen,"- the "Viper," and the: "Waterwitch." It may be sufficient to take the two trials at load waterline of the "Vixen" and the "Waterwitch." They approach nearer in point of draught of water, in fact, they are within an inch and a halfthe "Water'witch" drew nearly two inches more water than the "Vixen" did. The "Vixen" was $10 \mathrm{ft} .5 \frac{1}{2}$ in. formard, $11 \mathrm{ft} .5 \frac{1}{9}$ in. aft. The "Waterwitch" $10 \mathrm{ft} .10 \mathrm{in}$. forward, $11 \mathrm{ft} .4 \mathrm{in}$. aft. T'he result was, 
that the speed of the "Vixen" was 8.894, and that of the "Waterwitch," $\mathbf{9 \cdot 2 5 5}$, more than one-third of a knot in favour of the "Waterwitch." The
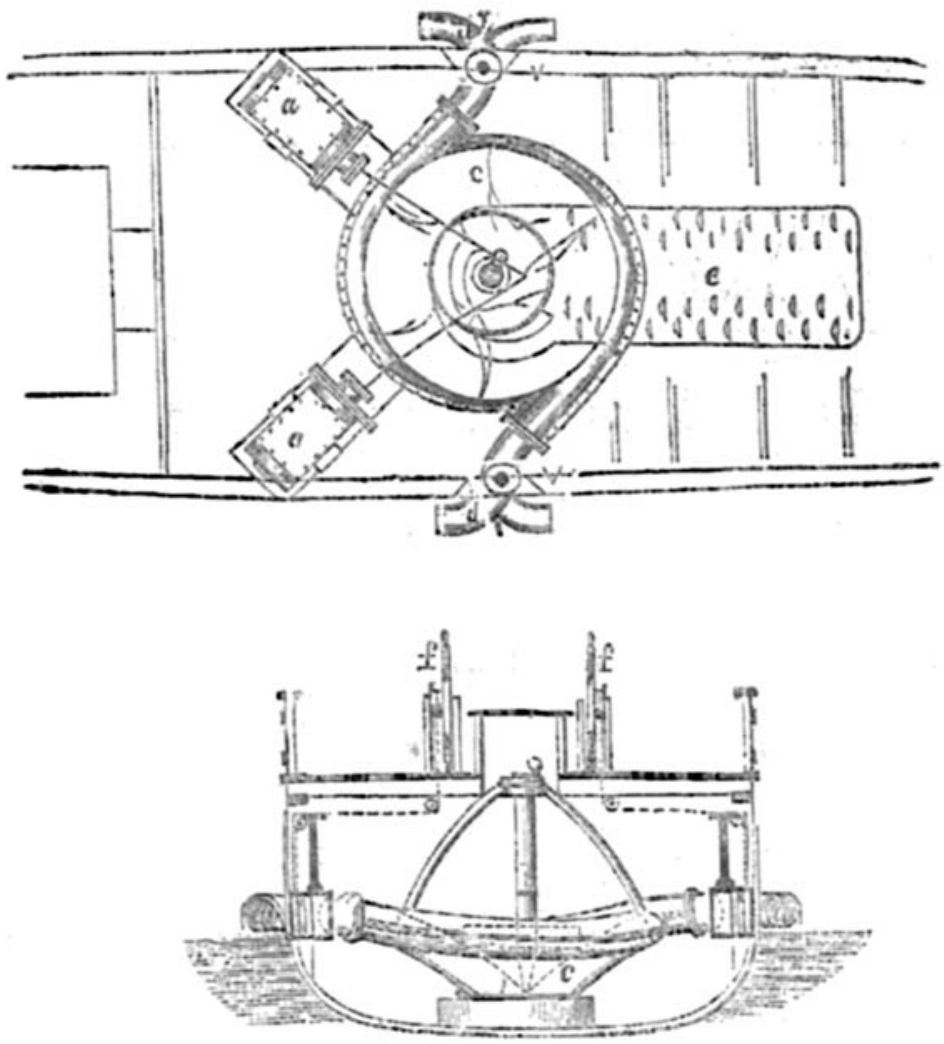

mean draught of the "Vixen" was $10 \mathrm{ft} .11 \mathrm{in.}$, the mean draught of the "Waterwitch" was $11 \mathrm{ft} .1 \mathrm{in}$. The co-efficients were, by the formula for sneed and midship scction, $317 \cdot 7$ in the "Vixen," aud 327.7 in the "Waterwitch." And by the formula for speed and displacement, in the "Vixen" $107 \cdot 4$, in the "Waterwitch" $109 \cdot 2$, both in favour of the "Waterwitch" as by Admiralty showing.

Now, Gentlemen, I believe that every one knoms that the essence of the whole affair is in those co-eficients. If the vessels were not exactly alike, the comparison would be no test of the ralue of the propeller; but where two vessels are exactly alike, midship section, displacement, draught of water, tonnage, the co-eflicients certainly do show, if anything will show, the comparative value of the two kinds of propellers. 
Having arrived thus far, I think we have a right to say, that we have facts, and we have a right to ask scientific men to accept those facts, or to give their reasons for not doing so. What I complain of is, that opinions are still expressed, and that unfortunatcly, those opinions have great weight towards a disparagement of this motire power. Those who disparage the system do not say, we have not done what we have done; they agree it is a success; but they now say, "when you come to try it on a larger vessel and with a greater speed, we do not beliere you will succeed so well." I should be very glad if they would come and tell me why. I think if it be done in a vessel of the size of the "Waterwitch", they ought to be able to show why it will not be done in a vessel of larger size. I, on the contrary, say that as you increase the power, so you will improve the comparative speed as regards other vessels. And for this reason, that there is no slip here, and in the screw we know, as you get higher relocities, you do increase the slip. I am coming to that question of slip presently. You may say, "there is water friction," but I do not perceive it as far as present experience goos. I have got rery good support from eminent scientific men with regard to fricion, that water discharges itself through its centre, and that there is but little loss by friction.

Ilaving given you a sketch of what has been done between the "Vixen" and "Waterwitch," I hare no time to go further into it. I shall be very glad to answer any question afterwards.

I now wish to show that these are not the only facts we have got. We lave a comparison between what the "Waterwitch" and what two vessels built by Mr. Dudgeon have done. They are ressels of the same type, the "Medusa," and the "Triton." I will show afterwards, as I go along, what MIr. Dudgeon himself says with regard to his vessels. IIere are the whole of his calculations, and he here says, guided by his co-efficients and comparisons-(he was on board the "Waterwitch" on all her trials, and he has taken the Admiralty evidence of her diagrams) - " I therefore conclude that about 50 or "60-indicator-horse power was lost in the water propulsion. As com"pared with the twin screw, it was about one-fifteenth of the power; "and as the twin screw ressel was fitted according to our own system, "the comparison is good." After that, I asked Mr. Dudgeon this ques"s tion: The 'Mcdusa' and ' 'Triton' had the same displacement, it is true; "but they drew three feet less water, and they were 30 feet longer. "Are they not an easier class of ships to drire?" Mr. Dudgeon, in his own words at the Society of Naval Architects, acknowledged that it was so; that although the displacement was the same, and the indicated horse-power was the same that was exerted, still drawing three feet less water and being 30 feet longer, they were an easier class of ship to drire, and he considered it quite made up for the loss in the comparative speed of the two ressels.

Therefore, we have substantial facts ; but I am sorry to say, they are the only facts at present, unless I mention those conmected with the "Nautilus," which vessel I am now about to refer to. This vessel was built at Blackwall by the patentec, Mr. Ruthven, at the expense of 
private gentlemen, for the purpose of practically proving the advantage of the hydraulic mode of propulsion. The liull of this vessel is somewhat similar to that of one of the "Citizen" river steam paddle-boats, being about the same lengtl, although much broader and ligher between decks, and fuller in the lines. She is fitted with two steam-engines, cach of about ten nominal horse power. The advantages of construction, so far as shapo and size of hull are concerned, are on the side of the paddle ressel. Any superiority shown by this experiniental vessel may therefore be confidently attributed to the propelling medium. The immense difficulty of inducing the public to attach value to what appeared so novel and extraordinary an invention, induced the owners to incur the expense of building this vessel purposely to prove the correctness of the inventor's calculations and the great value of the principle. Constructed on a model unusually full in the lines, and with no extraordinary power, this vessel may be considered to afford a serere and reliable test. The "Nautilus" having so completely fulfilled this purpose, the owners and patentec have invited the criticism of scientific mechanicians and the publie, confident that an inspection of the vessel and ocular demonstration of her performance, cannot fail to prove the great supcriority of this mode of propulsion for ships, over any other now in use. But, strange to say, this invitation has not been responded to with cordiality, or with any earnest intention of obtaining information by enginecrs and ship-builders.

A trial certainly did take place. A "Citizen" steambont, the "Volunteer," was hired. The Admiralty sent their Officers to witness the trial, and their report of it was, that they went down the rirer together, they kept pretty eron for a certain length of time, when the hydraulic gradually drew a-head and beat her-I forget by how many lengths. One of the Admiralty Officers attached to the Controller's department was on board the "Gitizen" boat; and he can testify that they did orerything in their power to drive her along, that it was as fair a race as could be. All wo then wanted was to get the indicator diagrans of the two ressels. "lhey were rery nearly alike. The "Volunteer" had two 12-horso engines. Sho drew a little moro water, had rather a more rising floor and less frictional surface, and therefore had better lines. Indicator diagrans of the "Nautilus," were taken, and we then asked to get the indicator diagrams of the other vessel. They were written for, offered to bo paid for, and I am sorry to say without success; we never could obtain them, and we never have obtained them up to this day. Upon that I wrote a challenge in the Standard newspaper to any "Citizen" boat on the Thames to a trial with the "Nautilus;" the patentees offered to pay the expense of the trial. I am sorry to say that offer was not accopted. Under those circumstances, I have a right to claim that they were rather afraid of us.

IIowever, I believe that the real cause is this, and it is a natural onc to a certain extent: - If this hydraulic principle wore to bo established, it would set aside an enormous quantity of enginecring plant throughout this country, and would probably disturb existing connections. And I have been told since, that if you goo into a ship-building yard, and propose 
to make any little difference in whatever is going on, it upsets the order of things; you alter the groove into which they have got, if you begin to introduce anything new. They say, that for these reasons it is evident that novelties create a loss of money; and we cannot therefore expect that engineers, who are making very good fortunes as it is, should be anxious to encourage $n$ new motive power. We must, therefore, push it forward in the best way wo can.

Well, then, in due time, as I have said, the "Waterwitch" appeared on the river, and her trials have proved, that to the extent of a vessel of 777 tons, and 160 -horse power, the hydraulic has equal merits as a propeller to tho screw or paddle. Now, then, comes the point! 1 am told that official and scicntific adviscrs say that it does not follow that the samo suecess will attend trials on a larger scale with higher rates of speed; in fact, that they express the opinion that it will not. I naturally asked for the grounds of support for this opinion, but that is not obtainable. Now, then, comes the point, the point at which we are stopping now. The ask for a progressive trial. We say to the Admiralty, "you have gone to this great expenso of making a trial "when the whole thing was under a cloud, when ererybody was in" clined to speak against it: and, now, that you have got a certain "amount of success, and when you see the enormous advantages, " (which $I$ an going to point out presently), which are likely to accrue "from it, surely you are not going to stop there. Iet us have a larger " ressel. This is a $\mathbf{7 7 7}$ ton vessel; you are going to build vessels of 6 1,200 tons, let us have one to put the hydraulic in, that is all we can " possibly expect, we do not expect to jump at once to the largest class " vessel; although we feel confidence, we do not expect everybody to "have the same confidence." All I ask is to have a progressive trial in a larger vessel and at greater speed. I think a great mistake was made in not building the "Nautilus," to make her the fastest thing to go on the river; if we had got that, we should be in a different position from what we are in now.

On my part, I give reasons, which are I think admissible, for saying that the same results must be obtained in larger vessels. What has been done in the "Waterwitch" is simply this : a certain amount of work has been done for a certain power exerted, and this, when compared with the twin screw in a sister vessel, shows equally good results. Beyond this, in order to test the value of the propeller more completely, and the accuracy of the effectire power of the propeller, a series of diagrams were taken at different rates of speed of the engine from 20 revolutions up to 40 , and the speed of the vessel dne to revolutions being known, it resulted, that the law, "that the power is as the cube of the speed," was fully exemplified. From 20 revolutions right up to 40,-I have got the paper here with the trials, showing the horse-power according to cubes of the speed, and addition for friction and variation, and the result is as I say-it came out, showing exactly, -that power is as the cube of the speed. We took those diagrains for our own information. I merely mention these facts to show that we are not trying to jump at conclusions, but that we have tried to satisfy ourselves by every possible means, and that our opinions are 
worthy of reliance. Surely, it will not be adranced seriously, that if you double the horse-power, it can place this matter on a different footing. If it has becn proved with a vessel of 160 horse-power, as it has been, it must act in the same way if you incrense the power. It is of no use discussing such points as these, where opinions are allowed to be expressed, and to influence decisions of such gravo importance, but where it is refused to submit the ovidence to the test of public scientific analysis. I have heard something about friction whispered in my ear. It was yesterday conveyed to mo that that was an objection that was raised; that as you get to a larger vessel the friction will be inereased; and I have also heard of increase of slip to be overcome. The truth, I beliere, is that there is little friction in the discharge of water through a pipe. Water discharges itself through its centre, and if the outer grobules are retarded by adhesion to the surface of the pipe; it results in little loss of power to the engine; and oven if it were so, to a slight extent, the larger the pipe hecomes, the smaller the frictional surface as compared to the increase of the column of water discharged; and, therefore, if it has answered in ressels of the "Waterwitch" size, this supposed loss of power would be reduced as tho engine power is increased. But I believo Mr. Ruthren will a cree that the loss due to water friction is of very little consideration, if it cxists at all. How does water flow through pipes for many miles, with the very slightest fall, with little alteration of speed? Added to that, in the discharge pipe of the "Wraterwitch," at the very extremity of the outlet, there is a sinall flange put inside to retard, as it were, the cuter globules, so that they may rest there as a cushion for the discharge of the inner water; and it is done expressly for that purpose. We have been often asked why it is there? People naturally come up and say, "Why don't you get that out of the way? "It is an obstruction." There it is, and we see no reason at present to alter our opinion. I wish I had thought of it, and invited a scientific gentleman who has had a great deal to do with the discharge of water through pipes, and who has written to me, corroborating cxactly what I have said. He says, "talking of friction, it is all moonshine, and I "can prove it." And his proof is, that the water discharges itself through a pipe through its centre, and that the frictional loss is proportionately lessened by increasing its velocity or increasing the size of the pipe. Therefore, I think we have a right to dispose of friction altogether, as a reason why we are to do worse in larger vessels. $\Lambda \mathrm{s}$ to slip, I maintain there is none at all.

Well, I will resume the subject of the " Waterwitch" and "Vixen" trials presently, and also show how, by comparison with two other vessels-the "Medusa" and "Triton"-the results have proved equally favourable to the hydraulic propeller, as regards the speed obtained. Having now a right to claim that so far, the hydraulic has, as regards speed, prored its equality to the screw, I wish to put before you in the strongest light I can, the enormous adrantages this propeller will introduce in other respects, more especially in war ressels. I hare lately rend a paper at the Society of Naval Architects which briugs to light in a most prominent manner the pro- 
spective advantages of the hydraulic propeller. It is not my intention to read this paper through, but I shall read extracts from it:-

"In all past times one of the grentest merits of a naval architect " has been to produce an easy ship in a sea-way, this being a great " element of sea-worthiness in all vessels, and of efficiency in a war "vessel, as affording a steady platform for the guns. I think the "starting point of uneasy vesscls was, when we put the first engines " into a ship of war. From that day, if my recollection carrics "me back, we began to find ressels roll more than they did " beforc. It was a simple cause. The rreight of the engine "placed upon the bottom of the ship was a great leverage. How" over, that weight might lare been countericted by weights " above, it was a great leverage to make a ship roll when a ship " was set in motion. 'The deeper the ship, tho more it will roll. The " natural conclusion is that if these engines could be lifted that will "disposo of the difficulty.. Then, when we added to that, armour "plate to the sides of ships, there was another leverage to make a " ship roll. And when we added to that, bow and stern batteries, " there was another great leverage to make a ship pitch. 'The over" hanging weight of the screw with fine lines abaft, is also another "element of pitching. Consequently, we have arrived at such a "state of rolling and pitching that our ships are unserviceable; and I "feel it almost a duty to endearour by any means in my porrer to "expose it and to stop it, believing, as I do, that it is quite unneces" sary and easily avoided.

"If anybody takes the trouble to read the licports of the Admirals "of the Channel Fleet, I cannot understand how he can.sit down for" " a day afterwards, and not endearour to put a stop at once to this " lameitable state of affairs. The reports are by $\Lambda$ dmiral Telverton and "Admiral Warden; and the way they talk about these ships and their " rolling is something frightful. Now, I knew of this before. I knew "it must be so, and I have almays said it is sure to be so. I havo "said, 'You are doing everything you can to make a ship roll;' amb "I think, when we hear the reports of the 'Royal Alfred,' the way 's sho is knocking about, it is really time we began to think of amend"ing our ways. The 'Achilles' I believe to be a steady ship. It is "something remarkable. I sce here, when the 'Caledonia' was " rolling 14 degrees, and the 'Lord Clyde' $10 \frac{1}{2}$ degrees, the 'Achilles' " only rolled two degrees. Somo of the rolling was 34 degrees and " 36 degrees. I cannot explain the cause of this good behaviour on " the part of the "Achilles," as I am not aware in what respects sho; "differs from the other ironclads.

"The greatest defect of our ironclads, then, is their marked pro" pensity for rolling, but the exceptional case of the 'Achilles' proves 6" that this defect admits of remoral in futuro vessels. If it is not " removed wo must attribute the fact, not to the difficulties of the " problem presented for solution, but to the negligence or incapacity " of the naval architect. It does not appear that arrangements tend" ing to reduce rolling would in any way interfere with those intended " to secure a high velocity under steam, and in any case it is ccrtain 
" that the efliciency of a fleet depends so much on the steadiness of "the ships as to make it expedient to sacrifice other qualities in order "to secure one of such paramount importance." "Admiral Yelverton " reports that in his opinion a turret ship "would have had a great " " triumph on this occasion.' The statement will, no doubt, be made "use of by the adrocates of the turret system." That is the reason I make use of it here. "The whole tenor of the report confirms in "the strongest manner the adverse opinions which I have always " expressed as regards 'Monitors.' Meanwhile, the turret-ship to "which Admiral Yelverton alluded is as far remored from tho " "Monitor' type as anything can well be. Ho writes, 'For there is " ' no doubt that a sea-going turret-ship, say 12 feet or 14 feet out " " of the water, would have fought her guns without the slightest " ' difficulty, and fired easily six shots to every one from our broadside " ' ship. I do not hero allude to the 'Wivern,' for the sen would have " "washed into the ports of her turrets, and swanped crerything " "inside."

There is one point there. Admiral Yelverton says a vessel of 12 or 14 fect freeboard. Why on earth should the turret-ship not have 12 feet or 14 fect freeboard? Whenever I hear of a turretship, I am always told she must have a low freeboard. I never could understand why she should have a low freeboard, except in the imagination of those who wish the sea to come in. I do not see why we should not have a turret-ship with a high frecboard of 12 feet or 14 feet, or even a great deal higher.

Inving introduced the subject of rolling, I then go to another feature which this paper, that I read, introduced. It was the immense importance that will be attached in future warfare, to running down vessels, to what we call "ramming." I do not know whether I am wrong, but I can fancy the sort of thing, and I know I should do it to-morrow if I was in the position. All my manourres, everything I could undertake to bring my ships into training, would hare one object in view, which would be to have the greatest power of "ramming" and running down an enemy's ships. I have heard that one of our Naval Oflicers has lately written a clever paper upon that subject. I should have been very glad to have seen it, but I am sure I go heartily with it. Who on earth will stop popping away with his guns, when he can go "bang" at the enemy and sink him by one blow, if you hit him with the spur. But a screw vessel can only strike with one end, the bow, whilst one with the hydraulic propeller can strike with equal force with both ends, and therefore the ramming power is doubled-a most important feature. With reference to this point, I will tell you what was done the other day in the "Nautilus," before 24 witnesses, going" ten knots an hour. We dropped a piece of wood orer the bow, and the ship was stopped, dead, in half her own length, when the pieco of wood was on her beam. And in ramming, if $I$ see that $I$ am likely to miss with one end of the ship, I can stop, and can go at full speed in the other direction, and I am sure to hit something in a melée. If, however, I have to turm a long ship like the "Achilles," my ramming power is very much restricted; therefore, I introduce vol. XI. 
ramming as one of the greatest advantages connected with this hydraulic propeller. I have a rudder at both ends, but I do not carc about the rudder, because I can steer without it perfectly well. But I have a rudder at both ends, and my principle in gum-boats is to fight with my stern towards the enemy, on the end-on principle. I will explain that presently. I will keep to the point I am talking of, viz., ramming, and I say that the hydranlic pomer alone, sccures this perfect system of ramming. It also gives you a great increase of tuming power, which is another element of ramming, for you can reverse the bow of your ship without turning at all, or move either end of your ship in the direction in which you wish to go, without making a circle.

I will now read what introduces the advantages of the hydraulic. At page 6 I mention, " $\Delta$ t present I really believe that a galo of "wind would almost cause as much damnge to the flect as a naval "action." Now, I have heard a good deal about the fate of the " Royal Alfred" going out the other day. What I hare said is, if one of these vessels should got caught in a heavy gale, and if from some accident to her engine she cannot use it, she will roll away her masts, and when she has rolled away her masts, I do not know what will become of her hull with the present momentum they have. The other day, with her engine intact, tho "Royal Alfred" carried away her main yard; she started away her chain plates, and very nearly lost her mainmast. What would huve become of her if her engines had stopped? We have never had an instance of that. I hare had engines stop in the old "James Watt," in gales of wind, unfortunately, at the wrong time. If one of these ships got into heary weather, and her engines were to be disabled, I think sho would be very soon dismasted; I do not think canvas or anything would stand that great roling. If she carried away her sails she would roll more, and would carry away her masts; and if she carried away her masts, she would perhaps lose her hull. Wo have never had a ship in that predicament; but wo have the evidence of Naral Officers who hare seen how ships roll, who tell us that it is time to go back to those old times when the great object of the naval architect was to make a good sea-boat, that is, an easy ship at sea. It is dne to officcrs and men, as they hare to contend against heavy weather and hardships of orery hind, that they should have confidence, that everything is done in the vessel they belong to, to make her as seaworthy as it is possible to make her.

I know the great difficulty of regulating weights so as to secure easy motion. In a deep ship the engines are low, and the leverage therefore great, and the armour belt is below the water line, but the whole weight of armour and guns has been placed on the sides of the vessel, with great weights placed in the extreme bow and stern, and thus all the elements of uneasy motion have been intensified, so that no amount of skilful designing could produce an easy ship.

I am very curious to know how the "Achilles" is so easy a ship as she is ; there is no doubt of it, I believe.

I do, howover, maintain that wo haro verlected to a great extent the importance of adopting all remedial measures to reduce, as far as posible, the causes of violent and oxtensive rolling and pitching. The 
great object to be attained, to procure easy motion, is to concentrate as much as possible all weights, not only vertically towards the water line, but also from the sides to the central line, and also from the bow and stern towards tho centre. The broadside principle is antagonistic to this. 'The bow and stern batteries are a part of this broadside principle, and are fatal to the sea-going qualities of a ship, therefore, the neglect of taking advantage of the turret principle has been a great mistake. To raise the weight of the engine considerably towards the water-line, and to get rid of the great weight at the stern, which the serow propeller necesitates, would remove all difficulty from the work of a naval architect. I am glad to say that this advantage is now within his reach by the adoption of the hydraulic propeller.

There is no reason whatever why the hydraulic propeller should not be placed near the water-line, if you like, engines and all; not one single reason. In fact, I believo it is the best place. If tho water is coming in through the canal under the bottom of the ship, the more that canal rises to the engine the easier the access of the water to it. Ind you may raise the whole weight of the engine to the water-line, and in that way it is a mere matter of cargo, you can place it whereever you like. But I would prefer the nozzles to be sufficiently low down, not to roll out of water, and to be out of the way of exposure to shot. And yet wo hesitate with such adrantages within our grasp! There is far more to be gained than that by this new propeller; yet it appears, that like the turnet-principle, it inight have to stem the tide of prejudice for a lengthened period, except that $I$ have great faith in the clear-sightedness and impartiality of the present Board of Admiralty. I have mentioned the hydraulic propeller as affording the means of facilitating, to almost any extent, the most adrantageous distribution of weights, by raising the engines to any height required, and by dispensing with the great over-hanging stern-weights required by the screw-propeller. I would also call attention to another important advantage of the hydraulic, as contributing towards a steady platform. The turbine itself is a contral weight, and from the great centrifugal force exerted, it will produce a certain amount of counteracting power to the rolling of a ship. You are discharging, I think, 350 tons of water in a minute in the "Waterwitch," from the turbine, and that is a great centrifugal force, acting as a steadinent to the ship.

It really is a most serious defect, that our present ships should roll about, as they do, especially when sails are furled; and what an unfortunate effect it would have upon the efficiency of a fleet when moving about in action, regardless of the direction of the swell. In heavy weather, I really do not believe that any spar or sails would stand the test of such heary rolling; and if that means of stendiment were gone, there is nothing for it but to bow the sea with steam power. If that fails and the dismasted hull is left to its own momentum-such a case was bad enough in olden times-but what would it be now? and naval actions generally leave ships dismasted. Surely, then we should grasp at every menns of so regulating the weights, that the easiest motion may be secured. The hydraulic, in this respect, will provo your best friend. 
In many other ways ought this principle also to command the attention of naval architects. If the water be discharged abore the water-line, the impediment to the speed of a ship, under sail, will be very slight, as compared with that caused by the screw, which, if not raised, is always a drag in the water, in addition to its retarding effect by increasing the sending and pitching of a ship in a sea-may. $\Lambda$ s the hydraulic has now proved itself equal to the screw at the measured mile by the speed obtained for the same power in similar ressels, it must be placed at great advantage, in a sea-way, when a ship is pitching, and the screw is making repeated visits into the air, because whaterer the ship may be doing in the way of pitching, the hydraulic power is always the samo; whereas, whilst the screw is out of the water, of course its power is entirely lost; and the steam that is being used to make thoso rerolutions in the air, causes a dead loss of fucl. 'Therefore, in a long voyage, 1 look upon it that the hydraulic must prove, as ayainst the screw, a rery great source of economy. Let any one get on to one of our headlands, and see a screw-steamer trying to get round, with a foul wind; he will seo the screw as much out of the water as it is in. Here is a great loss of fuel; a loss of speed; a great strain on the ship and engine; and, by prolonging the voyage, another cause of loss of money.

Another source of economy which the hydraulic provides, is when steaming and sailing. The speed of the screw must approach the speed obtained by the sails, before it acts as an auxiliary, and the steam which is expended in reaching that speed of engine, represents a dead loss of fuel. But the hydraulic propeller, when acting as an auxiliary to the sails, developes its whole steam power as an additional force; therefore, this must produce a great saving of fuel.

When the screw is superseded-as I feel convinced it will bethe naval architect will rejoice to find himself unembarrassed in designing a sailing ship, both as to the form of ressel, and as to the position of weights; and I believe that the nation at large may rejoice to see in the dawn of this new motive power, a revival of her maritime superiority, because it admits of a return to a more perfect construction of sailing vessels, and when good seamen will again become an essential feature of the strength of our sea-girt isles. Again, the hydraulic propeller causes no vibration, so that a great cause of discomfort is removed, and the weight and expense of strengthening a vessel to withstand the ribration of the screw, is avoided. Again, the hydraulic propeller will prove itself most valuable in reducing the danger of collision, as the officer in charge of the deck will have the power of stopping the ship in twice or thice her orn length from full speed, by reversing the nozzle-ralres; and this power is under his immediate command on deck, without any orders to the engine-room. The handles to turn the nozzles are brought up to where the bridge is (see f.f. fig. 2); in fact, where there is sure to be somcbods, who, at the word "Stop ler!" would have nothing to do but to turn tho nozzles round; and there is at once the whole power exerted to make the ship go astern. I have said, "in twice or thrice her own length," because, although the "Nautilus" stopped in half her own length, she is a very light 
vessel. Mrany a man's lifo and much valuable property would be saved by this facility of not only stopping, but of returning to the spot where the man fell, without turning the vessel round. Ifaving a rudder at both ends you can steer right up to the man; and I believe you would pick up a man quicker by the ressel than you would by lowering a boat. In fact, I have tried it with a piece of wood, and we could have picked it up in a shorter time with the ship than by lowering a boat. I consider that all now vessels with the hydraulic propeller will be shaped alike at both ends, and thus obtain equal speed both ways. This feature is invaluable to war ships by doubling the destructive power of ramming, which, I am convinced, will become the great element of sea-fighting. Iraving a ship, shaped aliko at both onds, will be acknowledged, I believe, by everybody to be no detriment to speed, nor any objection as regards sailing or sea-going qualities.

To excmplify what I have said, I will give an instance of what has occurred quite lately. A ressel called the "MIary," whilst in the act of sounding, found herself in shoal water, on the edge of a bank. Owing to the orders, conveyed to the engine-room, having been mistaken, she was carried further on, and, before the mistake was rectified, she struck the bank henvily two or three times, abaft, and tho first time she struck, the starboard screw and end of shaft broke off and disappeared at once. The ressel had no other damage done to her liull. The "Mary" was the property of the Messis. Dndgeon. Now, with the hydraulic propeller, nothing of this kind would have occurred, as no orders are required to the engine-room, the directing power of the engines being under immediate control on deck; and in caso of a ship striking the ground, whilst the screw is always subject to damage, the hydraulic is safe.

Again, tho hydraulic engine, acting as an enormous pump, will discharge from the hold upwards of two tons a miuute per nominal horse power; so that with an engine of 500-horse power nominal, 1,000 tons of water a minute would be discharged in case of shot-holes, or a leak, admitting the water, and there is no possibility of choking so large a discharge-pipe. If the holes were large enough for a man to come in with the water, he would be carried right through, and go ont at the discharge-pipe; and I look upon it as a most important feature, that by merely closing the sluices, you can then discharge the water from the ship itself.

Again-(you will think I am never going to end with ny advantages of the liydraulic propeller)-the hydraulic propeller can nerer be fouled, whilst the screw is easily disabled by floating obstructions in the water, as the nozzle can be protected by a shield, or placed under water out of harm's way ; in action the motive power would be always safe, whilst the screw and sternpost must be, to a certain extent, exposed. I sec that Admiral Yelverton remarks upon that; he says, he thinks he must be a very bad gunner who would not knock away the rudder of the "Bellerophon." when she is pitching, at the first shot. IIe mentions this in his Report to the Admiralty.

Now, on the question of speed, and as proof of the success of the hydraulic propeller, I am justified from letters I hare received from 
Mr. Dudgeon, and from the Admiralty reports of the trials of the "Waterwitch," in stating that sulstantial evidence on this point has been obtained. It is true, Mr. Dudgeon constructed the engine of the "Waterwitch," but he is known as the special friend, and the most successful designer of twin-screw vessels, and I believe his vessels hare equalled the best speed of the single screw or paddle. And I consider it most fortunate to have obtained the adrantage of his ability and generous support in dereloping this new motive power, knowing that his opinion is devoid of all prejuctico.

I wish to call special attention to the fact, that the naval architect must have greater command of speed with the hydraulic propeller than with the screw, because the screw is always limited as to diameter, and supposing unlimited power be given to a screw-engine, as you increase the number of revolutions, the resistance is increased on the bows of the ressel, until the loss by slip gradually increases, and so you arrive at last at a point when the serew is making all slip.

But the turbine has no slip, and you may have several turbines in one vessel; and to whatever extent you increase the boiler power, so you increase the speed, under the law that the power is as the cube of the speed. So, if yon wanted to go 20 or 30 linots an hour, the only possible way of attaining it is, by the turbine, because you cannot increase the diameter of the screw, nor can you multiply them; you may increase the power of the eugine, but, when you get up to a certain point, the power would be so great, that the screw would be all slip.

The battle between the turret and the brondside principles has been always fought on the merits of punnery questions alone, but there has been another very important question at issue, and that is, as to the most advantageous distribution of weights; and now the liydraulic propeller presents the same consideration as compared with the screw, only to a much larger extent. The turret principle and the hydraulic propeller, when combined, will solre all difficulties attending the creation of an armour-clad ocean fleet of the line: and I do earnestly hope that before another large ressel is laid down, a total change may take place as to the sea-going qualities our ships are to possess for the future.

For an hydraulic gun-boat, I recommend the end-on principle of fighting; as of old, with a heary gun behind a stout shield, and no attempt of broadside armour protection; the bow rendered unsinkable, before the shield, by partitions filled with cork, to the level of the waterline. I merely mention this lecause the model on the table happens to represent this principle, and it is what I suggested should be applied to tho "Waterwitch." Then, by keeping the stern of the vessel on, towards the enemy, I could always retreat without turning round. $\mathrm{My}$ opinion is, that the end-on principle of fighting is a necessity, for gunboats, and that such a gun-boat wonld prove most mischierous against large ressels for coast defence. That is to say, with that heary gun, and that thick defensive armour-plated shield, and with the bow protected in that secure manmer, I could, with one of these gun-bonts, in shoal water, drire oft any armour-clad; nor do I think an enemy would 
run the risk of cxposing so large a vessel to destruction by a small gunboat of such a character. I think, myself, that that character of gunbont will become a rery formidable weapon for the defence of our coasts. I an sorry they would not allow me to fit the "Waterwitch" in that way, but the day will come.

In one respect, particularly, I hopo that I may be in error, but judging from the reports of Officers in whose opinion I have great confidence, I really do not believe, that, with the exception of the two first that were built, the "Warrior" and "Black Prince," and perhaps the "Achilles," we have an iron-clad in our Navy which could be safely trusted, if placed in the middle of the Atlantic in the winter time, were she to break a screw shaft, and if heary gales and continual bad weather were to come on. Another thing is, that in action, vessels get their masts knoched away, and then with the screw shaft disabled, they would be at the mercy of the waves, and I really do not know that would becone of them.

Some of my remarks may bear the stamp of unsupported doubts and fears, but I am willing to bear the burden of this accusation, and shall be quite content to do so, provided what I havo said may hare the effect of producing a greater degree of consideration in the future of armourclad designing, to the matter of the safety of our ships at sea, and to the classification of ships.

I would just refer to what was said by MIr. Reed with regard to my paper, as regards the "Vaterwitch." He says :- "With reference to " the hydraulic system, ho should be very sorry if what he said should "be construed into an opposition to that system, because it was very " undesirable that a system which had started so well as that had "started, should encounter any prejudiced opposition. In the first "place he thought the twin-screw ressels - he did not mean "MIr. Dudgeon's, for he had not the pleasure of seeing them-with "which the 'Waternitch' had compeied were about the most "wretched specimens of vessels 'as regards propulsion, that could " possibly be produced." I am sorry $\mathrm{MI}$. Reed should have siid that. First of all lie built them himself; and, independently of that, I do not know that that lias anything to do with the trial of the two motive powers. He says :- "The 'Vixen' and 'Viper' were little more than " shallow floating boxes, very heavily burdened with armour plating, " of very light draught of water, and with very full bows and sterns, " and he might say that they had the double stern chicfly on the "s ground that it gare them more displacement. The "Waterwitch,' is as compared with those resscls, had this advantage, that whereas "they trimmed afoot by the stern, the "Waterwitch' had the same $\because$ maximum draught, an eren keel, which had the effect of enabling " them to fine the lines a little. It could hardly be admitted that a com" parison between the principle of the 'Waterwitch' and the screw " principle was sufficiently established by the competition between her " and such ressels as the 'Vixen' and the. "Viper.' At any rate the ": 'Waterwitch' did better than they looked for, and no one could fail " to appreciate many of Admiral Elliot's suggestions as to the advanst tage of the hydraulic system as compared with the screw." I merely 
mention what MIr. Reed says to show that, generally speaking; he rather conveys the impression that tho "Waterwitch" was a success.

My reply to what he said was as follows:-C Mr. Reed had endea" voured to show that tle trial of the "Waterwitch" was not trust" worthy evidence of success, becuse the 'Vixen' and 'Viper' were, in " his opinion, "the most wretched specimens of vessels as regards pro" " pulsion that could possibly be produced, and because tho ' VVater" ' witch,' although a sister vessel, liad both ends shaped alike, and " "was of the same maximum draught, but on an even keel, which had " ' enabled them to fine the lines a little.' Now ho (Admiral Elliot) " would put it to the naval architects present, whether, as the vessels "were of the same type, it was not as fair a comparative test of the " propellers to do the same work, for the same power exerted in coarse "lined ships, as in those of finer lines? And also he would ask whether "it was possible to obtain finer lines in the 'Waterwitch' than in the other "vessels, with the same length and breadth, and same midship section, "and greater displacement, and the same maximum draught of water? "Comparing the lines of the two vessels, it bccame evident that the " "Waterwitch" was at a disadvantago in point of form to the "Vixen' " and 'Viper,' and a very clever naval architect had given a decided "opinion that it was so." Then, with regard to Mrr. Dudgeon, I asked, "Whether, considering that his vessels, the 'Mredusa' and 'I'riton' "were $3 \pm$ feet longer and 3 feet less draught of water than the " 'Waterwitch,' and therefore casier driven ressels, although of the " same type and the same displacement, he did not cousider that the " hydraulic propeller had shown equal merits to his twin screw prin"ciplo by comparison of results of speed?" Mr. Dudgeon assented to it.

I will merely mention these remarks of MIr. Scott Russell :- " IIC "was not known as an adrocate of that principle. IIe had known of "it for two generations, and as far as he knew the relative value of " propellers it stood thus:-That the paddlc-wheel, the double-screw, "and the hydraulic propeller were, theoretically, equally good. Out of "them all they could get the same speed, and it was a mere matter of "luman ingenuity, in which he had infinite faith, applying ench pro"peller so as to get out of it the specinl qualities and the speeds " required. He would undertake to say that a hydraulic propeller, a "double-screw propeller, and a paddle-rheel with the same power of "engine, would all gire the same speed, but under very different cir" cumstances, with very different combinations, and with very different "clements of construction. Therefore, he would say to Admiral "Elliot, "Go on, fecl your way, puzzle your brains, get as many " clever mon to work as you can, and go on with your hydraulic pro"' peller, and I promise you in the end, that you will certainly " 'succeed.' I do not say that you will erer get moro speed than "you will out of the others, I will not say it will not take you a long "time to get the same speed as the others-I won't say that you hare " not a deal of trouble still to take, and a monstrous quantity of "ingenuity still to throw into it before you can get your wheels con"veniently placed, and before you can get your large orifices for a 
" ship of large size so constructed that your machinery shall work " handily, but I promise you, if you go on you will get it."

I have only a few words more in couclusion; I must apologise for the incompleteness of my preparations for reading this paper, but I trust I have laid before you sufficient evidence of the importance of this subject to secure from you an interest in its early dovelopment. At present the fate of this inrention is in the hands of the Admiralty; they, having in its earlicr stages, when all was dark and suspicious, considered it of sufficient importance to make so costly an experiment as the "Waterwitch." I do trust that now so much success has attended this first trial in a war ressel, they will not delay in making a further trial in a larger ressel, with greater power, intended for high velocity. I ask for one of the new correttes of the "Blancho" class, 1200 tons and 350-horse power. This would be a most satisfactory trial, and four of those ressels are to be built this year. I wait in hopes of a favourable reply to my request.

Tho Crumsuras : This is a subject that interests us all rery much, and $I$ have no doubt there are many gentlemen here who will be glad to gire an opinion upon it. I will ask Admiral Elliot to take a note of the rarious points that may be raised, so as to enlighten us as to the merit of tho objections that may be made. For mjself I would wish to ask him two questions: One is whether the discharge of the water from a turbine, if unäer water, would not gire a greater porrer of propulsion than if it were at the rater's edgc and exposed, as haring a greater resisting medium to act against? Next, when he spoke of the ramming, how far we should be able to hare a solid fabric, with rudders, at the two extrenities of the ship, capable of ramming an encmy satisfactorils, either one end or the other? If we can do that, it would be a rery great adrantage. But the rudder, I think, would be rather antigonistic to the eolidity of the two ends. Those are the only tro points I would like to ask him about.

Captain C. II. Snursox, R.N.: I would like to ask one question. Admiral Elliot has stated that there is no slip on the hydraulic principle. I alwajs had an idea that the slip was the velocity of a propeller orer that of the ressel. In the hydraulic propeller the water is the propeller. I would mish to ast if the water issues from the tubo or nozzles with greater relocity than the rcssel mores? and if it is necessary that it should do so? Because if it mores at greater relocity, it appears to me that the excess of relocity of water orer the relocity of the ship must be the slip. I would also like to ask why there is this extraordinary poirer displajed in the hydraulic principle in stopping suddenly? I wish to ast what is the causc of that power? It is a special thing belouging to the hydraulic, and, therefore, must lare a special cause. My object in ashing that question is, because I think that the same cause that gires that porrer to the hydraulic, is tho rery cause that will, at high speeds, make it inferior to other propellers.

Admiral Sir Jayies IIOPE: Irow do you propose to protect the propeller?

Admiral Elrrort: With a shicld.

Sir J JMES IIOPE: Is there any position for these propellers which would be more adrantageous than another for speed?

Admiral FLlior: We think the propeller just abore mater is the best position. We tried it in the "Waterwitch" first of all, with the nozzle out of water; then we sunk the ressel down, and tried it with the nozzle in the water, completely immersed; and haring compared the speed at liglit draught and at deep draught, as against the speed of the "Viren" at the two draughts, we found, as far as we could ascertain, it did not matter at all. But the reason we think it better to hare the nozzle just abore the water is, that the freer the discharge of water, the better for the re-actionary porer by which you obtain your specd to go abead. If you dis- 
charge your water into a racuum, by comparison, you will get the greatest adrantage from it. Therefore, if mater, by being discharged against water, is retarded, we think it is rather a hindrance. If you close the mouth altogether, no action will take place; if you open it slightly, a small action is obtained, and small speed; the freer it goes out the better. But we do not belicre that there is anything so important in it but that it can be put domn under water.

Commander Coloum, R.N.: It is rather late, but I should like to make one or tro rcmarks. Admiral Elliot somowhat disparaged the Deronport experiments, and said they were not fathered by the inrentor. That is perfectly true. But at the sane time, the Deronport experirents mere sufficient to show the ralue of the mede of propulaion in a certain degree, and I belicre gare a rery considerable push to the inrention at the Admiralty. The experiments were tried in a gun-boat of 60 horse-power, the "Fan," which expelled the water driren by the ordinary engines of the ship. The relocity of dischargo from the pipe was 2,190 fect per minute, and the loss, which Tould be actual slip, or frietion, or whaterer you call it, was 205 fect per minute. The dynamic pressure, at that number of rerolutions, with an indicuted horse-power of 173 , was $1,412 \mathrm{lb}$. It was found, and this may be an answer to the Chairman's question to a certain extent, that the dynamic pressure inereased from $150 \mathrm{lb}$. to $200 \mathrm{lb}$. when the nozzlo was placed below the water. I am not going to attempt to explain why it should bo; I cannot see myself why it should be. 'Though there appears to be from these experiments some slight friction, yet $I$ beliere that it is mrong altogetlier to look at the question as involving frietion, beeause the power in this mode of propulsion is giren by pressure; and the only way to understand it, I beliere, is to consider it as a pressure, and as a release of pressure. The travel of the fan of the pump is sulficiently great to generato a certain pressure in the pipe leading to the outside of the ship. Now, pressure on all sides of that pipe is equal, necessarily. You open a portion of the pipe, and you take off that, by opening, the pressure which previously existed there, and you liare, as the remainder, the pressure upon the part which is opposite to it; and that is how you get your power. If you take friction into account, I think you immediately get into a mazc of difficultics from which I sce no pussible exit. Admiral Elliot made a great many remarks about rolling. I cannot say I lnow rery much about the subject, still $I$ hare looked a little into it, and $I$ hare had the opportunity of witnessing a practical contradiction to some remarks which the gallint Admiral made. He said that he thought rolling came in with the steam-engine. Now, $Y$ hare served in a great many ships, but the heariest roller I crer serred in, without exception, or crer cxpect to serre in, was a Symondite brig. The gallant Adnirul also expressed it, as a certainty almost, that the placing the weights at the cxtreme of the beam, as thes are placed now, with heary. guns aud iron-plating, necessarily increased whaterer rolling powers the ship might previously lare had." The other night I quoted here some experiments of Admiral Paris. IIe tried rery aceurate experiments in a small ressed, and he found that as he placed the wcights towards the extreme of the beam, so the rolling of that ressel decreased. I do not believe that the rolling of our ships lins rery materially inereased, except in the case of rooden ships of the "Caledonia," "Royal Alfred," "Royal Oak" class. In the case of the "Warrior," I liappened to be present during her first official trial, and I recollect that her rolling power, as compared with that of the "Rerenge," which was a rery steady ship, was only 20 degrees to 17 degrees. But I am inclined to demur altogether to the records of the rolling of our ehips. I an inclined to demur to them, because we hare nerer had any proper instruments for measuring the rolls. On board the slip. I was in in the Channel Flect, we tried from time to time to get at the ideas of different Officers as to the rolling of the ship at particular times, and we found that those ideas raried immensely. I am very glad indeed to get another confirmation of my idea that the ram is to be our future weapon; and in corroboration of what Admiral Elliot has spoken of as regards the necessity of arming the stern for ramming, as well as the bow, $I$ nay say that the Russian Admiral, Boutakor, has pointed out in his work on naral tactics the great necessity for this. It is a point he has urged rery strongly, and I agree with him; and I agree with Admiral Elliot also that it is a wost iupportant matter. I hare only one word to say about another adrantage of the hydrulic which 
I did not gather, that Admiral Elliot brought forward. I look upou it that the liglraulic propeller will enable us to increase the beam of ships, and thereby reduce their length, while at the same time retaining their mass. That is, we may increase the lateral area of the nidship scetion, while we take off from the rertical one, and thereby we shall get a handier ship, at a lighter draught of water, to do the work which is now done by a longer ship, with a narrow and decp midship section.

Captain Ricisad WELIS, R.N.: I should like to ask whether the space taken up by the engine-room, the turbine-wheel, and the well for receinng the water, is greater in vessels of a similar class than the space taken up by the engine-room and the machinery in an ordinary serew ?

Commander PoLisi, R.N.: In the casc of getting on shore, I should fancy the power of the turbine will be entirely destroyed, or nearly so, should the ressel land on sand, which would fill up the holes in the bottom.

Adniral EnIIOT: The first question, I think, was with regard to the discharge of the water above the water-line and below the water-line-whether it was an adrantage? I think that was the question that was put. I hare just described it to Admiral Sir James Ilope that it is a question which is undecided; there are different opinions upon it. An eminent French engimecr makes it out that it is better under water; that increased power and increased speed will be obtained. Mr. Ruthren thinks the contrary; but as regards the effect of rolling motion, it will probably be better that the discharge-pipes should be solow down as not to roll out of nater. But it is a question not decided. The next question was with regard to the weakness of a double-ended ressel, in conscquence of the rudder. I think if the end is shaped so that the blow is struch here (pointing), if that is backed by the ressel, particularly where the deck is, that if the blow is struck there, I do not think you will weakeu it by haring the rudder here. I think the rudder may be lower down than this is. This rudder has a much larger surface than the ordinary rudder of a ship. But you may lower the rudder and take a picco off the top, and you will still hare suficient surface for steering. I think that that weakness may be redued. I do not think it will signify; it is a question for the naral architect to arrange. Dut I do think jou will be able to hare a perfect ram at both ends, and hare a rutder underneath; by building it for the purpose. I should say that, in the case of ramming, we hare seen cnough of it to know, that this picce the spur should not bo a part of the ressel at all, but that it should be capable of bcing taken off, learing the ressel intact afterwards, not to open the ressel out if you lose jour spur. The nest question was with regard to the power of stopping the hydraulic, as compared mith the ecrem. I could not quite understand that question. The rhole power of the engine is inmediately applied, in almost a second or a few seconds, to stop and to go astern. You merely reverse the nozzle ralre, which is like a tap in a becr cask, and the water, instend of flowing out in one direction, floms out in the other, so that the whole force is exerted to drive the ship the other way. If you could instantancously reverse the paddlewhel you might get the samo power there, but jou cannot do that suddenly. It is quite the rercrse with the ecrew. When you come to stop a ship going ten knots, and to turn your serew astern, in the first place it is a long operation. It is a great strain upon your engiues; and if you look to the shape of the screm, and the cffect it lias, you would find that if you were to go as fast as yon could astern, fou would produce little effect. Fou might go 14 linots ahend, but I question whether your ship would go 4 or 5 hnots astern; and certainly you cannot stecr, bccausc directly you corne to back with the serew, the ship's bow is sure to go (according as it is a right-handed or a left-handed ecrers) in the opposite direction. I found in narrow channels I could not usc the screw astcrn. Dircetly I did, it threw my borr round, and it would hare put me right ashore. I remember also in the Baltic a ship attempted to back with her screw, to kecp astern of the Admiral, and she run her bow right into the flag-ship's quarter.

Captain Surrsox: Then the paddle would hare the same power in stopping as thic hydraulic?

Admiral Ezuror: I think it depends upon how the paddle floats are placed for going ahead. If thes are rertical, of course they would lare the same power; but you would still lare to discouncet, rererse your whecls, and that is a long operation. 
Captain Srmpsox : Rererse the cngines?

Admiral Exlior: Rererse the engines. Fou hare a certain amount of machinery to sct in motion. The next question, I think, was with regard to the slip, whether the water was discharged quicker than the ship goes. The water in the "Waterwitch" is discharged at about double tho speed the ship is going, whaterer the specd of the ressel may be. But there is no slip; and the best proof of it is that you obtain the same result with the same power.

Captain Srsrsoy : But if the rater is the propeller, and tho propeller is going with greater relocity than the ressel, surely the excess of the relocity of the propeller orer that of the rcssel, is slip?

Admiral ELIIOT : There is no such thing as slip nor loss of power, as supposed by Captain Simpson. The power is obtained by reaction from the water discharged. Whaterer the speed of the ship, it does not lessen the effect of the reaction due to the amount of pressure produced in the discharge pipe. B5 way of comparison, if a ship were going 50 miles an hour, and you fire a gun right astern, the speed of the ship does not lessen the recoil of the gun. Nor docs it lessen the recoil, or rather the reaction produeed by the discharge of water from the discharge pipes.

The Deronport experiment I should like to refer to. What I said was, that the experiment was made without auy reference to the patentees. No question was cver asked of the patentees, as to hor that experiment should be carried out, but I can assure my good friend Captain Colomb, that his information to-day is the first information I erer receired, either by word of mouth, or by letter, as to what the result of that experiment was. I was nerer told. I did not bnow whether it was successful, or whether it was the rererse. It was kept very secret. Tou hare let out a great secret, and I am glid to hear the experiment had such a good result. There was no report made to me; and as I said, MIr. Ruthren went down, and Eecing it was no child of his, he abandoned it. But I think that when the Admiralty ordered the experiment to be made, we might hare been consulted as to the mode of making it. A question I should like to answer is, with regard to the rolling of the Symondite brig. I could understaud the Symondite brig rolling. I have been in a Symondito brig myself, and I should like to ask a counter-question to that, which is, "Did you erer go in a Sfmondite after she had an engine in?" because, I think if sou did, sou mould find she rolled a great deal more. Wo hare only to take the "Colossus," and ressels of that class, in which an engine was put, and it was acknowledged that they rolled a great deal more afterwards. I think that spcaks for itsclf, that it is the reight of the cngine that causes the rolling. Then, with regard to the spreading weights out to the side, haring stopped the rolling. I erpect if we had analysed that, we should find that the meights that were put to the side, was ballast that was "winged" up. I know that in many instances where they "winged" up ballast in Symondite ships, they found it rcduced the rolling. But it was not beeauso the ballast was "winged" up that it reduced the rolling; but it was because you raised the centre of grarity, and that reduced the rolling.

Captain Conosrs: The balance was on the same level, througlout.

Adminl ELIIOT: I go upon the broad principle that centralised reights decrease the leverage and reduce the rolling, cateris paribus. Then with regard to the question of increasing the beam in an hydraulic ressel, I do not ece that the hydraulic facilitates the increase of the beam, but it does the reduction of the draught of water. I think in a light-draught-of-water vessel, fou can get greater speed than with the ecrew; as you decrease the draught of water, jou injure the power of the screw. With regard to that, the turbine need not bo under water. If the bottom of the turbine is in the water, the moment you set it in motion you cause a racuum, and the pressure outside will fill it up. Therefore, in rery light draught of rater, you can get great relocity, whereas you cannot do so by any serew. Mr. Dudgeon, in his recommendations to the Irazilion Gorernment, speaks of that. Ire says, if you want great speed in a light-driught-of-water ressel, I must take the turbine for it. With regard to a question as to the relatire spaces required for the hydraulic engines and those for the screw machinery in ressels of the same class, the "Waterwitch" engine is placed in exactly the same space as the engine of the "Viren" and "Viper." When I found that the screw passage was available, was 
a space that I was going to lose, I asked for that same area to be giren into the engine-room. It is added to the stoke-hole, not to the engine-room. The cngine is exactly in the same place. But if jon go and ninessure the stoke-hole, you will find there is a rery fine stoke-hole, adding a couple of feet for the stokers. But the principle is weight for weirht, space for space, price for price, and speed for speed. Now, there is another question that $I$ am rery glad has been asked me, about getting on shore. I would not speak of it, because I thought it might be put. We must first of all ask, what do we go on shore upon? If we go on shore on rocks, I do not think anybody will say that the water will not come in. But as the canal of the turbine forms a double bottom, and as there are additional kelsons, the strongest part of the ship is, where the canal is. If we go on shore on mud, wo know quite well, that if jou put the hydraulic ressel on mud, you can rork your engine; it is mud and water that comes through, and you can soon work a hole under the ressel-there is nothing to stop it. Sand rould do tho same thing. We hear of getting ressels off now, by stirring up the sand below, and pumping it out of the ressel. Here is a turbine that will do it for jou. If you make a hole under the ship on a sand bank, the sand will crumble in; but I think this turbine mill some day be found to get a ressel so circumstanced off. If jou put your vessel on stiff clay, perhaps Jou could not stir that clay, but there is generally ooze on the top of the clay. But supposing there is ans objection to the canal being under the bottom of the resecl, we could just as well, instead of letting water up into the turbine by the canal from below, let it into the turbine from the side. What we asked to do the other day with a wooden ship was to put it there. There is no reazon in the world why you should not open the side, and make the canal on cach side of the ressel. I think that I hare now answercd all the questions.

Captain Isgres, R.N.: Could you drire your ship through a heary head sea?

Admiral Elcior : I think that question -was answered just now, that so far as the turbine is concerned, the power is always the same.

Captain Ixanisr: Would the head sea check you sooner than it. would check the screw?

Admiral Ectrot: I should say, certainly not, because the screw is out of the water, and you lose a portion of your power; but with the turbine the same power is alrajs bcing cxerted.

The Cinsmuras : I ant loth to stop any further questions, but the hour is rery far adranced, and I think we are prepared now to close the discussion. We hare all had an opportunity of spcaking; but $I$ think there is one thing that all agrec upon, whether we think the plan is successful or not, that is, that we must be rery grateful to Admiral Elliot for bringing it forward, and for the way in which he has put tho rarious facts before us. I must say, there is much to learn; I, at least, lare learned a great deal myself, and I hope we hare all leamed much from the paper. Eren the rcmarks that have been made, have elicited what is rery valuable. $\Lambda$ s I said before, we are all very much indebted to $\Lambda$ dmiral Elliot for his admirable paper.

Adniral Elliot: I hare only to return my grateful thanks for the patient manner in which you hase heard what I hare had to say. 